\title{
CLIMATE CHANGE AND ADAPTATION IN THE MUNICIPALITY OF BEMBEREKE, MALANVILLE: CASE OF MAIZE PRODUCTION
}

\section{PARAPE OTO ISSA ABDOU-RAOUF, KISSIRA ABOUBAKAR \& ASSOUNI JANVIER}

Department of Letters, Arts and Sciences Human, University of Parakou, Benin

\begin{abstract}
In Benin, as in several underdeveloped countries, producers are faced with a drop in their productivity due to climate change. The objective of this work is to analyze the effects of climate change and the various adaptation practices implemented in the municipalities of Bembèrèkè and Malanville. A methodology based on the typology of practices, Multiple Correspondence Analysis, chi2 and ANOVA were used. The analyzes carried out show that 99.3\% of producers have perceived climate change. According to the classification of the different practices adopted, the fourth group is the largest group in this classification. It contains nearly half of the farmers surveyed (40\%). When choosing a random individual from this group, there is a $96.77 \%$ chance that they will use conservation practices; $100 \%$ chance of it doing crop rotation; $98.39 \%$ chance of double seeding and $96.77 \%$ chance of increasing pesticide use. The experience of farmers, the area does not determine the choice of a socio-economic practice by a producer. Only the level of education of the farmer determines the choice of the farmer

KEYWORDS: Climate change, perception, adaptation, Bembèrèkè, Malanville
\end{abstract}

Received: Nov 06, 2020; Accepted: Nov 26, 2020; Published: Dec 03, 2020; Paper Id.: IJECRDEC20207

\section{INTRODUCTION}

The international scientific community is unanimous about climate change: it is a real phenomenon, the effects of which are already being felt in some regions (Canada, 2004). Climate change has global repercussions, but those most affected are often those least equipped to deal with it, and this is already a sad reality for millions of people (EU, 2015). According to the same source, climate change can undermine development efforts and reverse progress made in the fight against poverty. To this end, it is therefore reasonable and essential to combine efforts to help States and individuals to face the climate challenge (EU, 2015). Agriculture in the broad sense has a particular economic weight in West Africa since in the WAEMU zone for example (Benin, Burkina Faso, Côte d'Ivoire, Mali, Niger, Senegal, Togo, Guinea-Bissau), it contributes 30\% to the GDP and employs more than 50\% of the working population (Renard et al., 2004). The agricultural sector remains very preponderant in the Beninese economy and employs around $75 \%$ of Benin's active population with an average contribution of $1.3 \%$ to national economic growth over the period 2001-2010 (DSEE-INSAE, 2011). In Benin, during the period 1971-2010, the number of rainy days has been steadily decreasing while temperatures are increasing (BIPEN, 2012). On an annual scale, the decrease in precipitation is between $11 \%$ and $28 \%$ (MEHU, 2011). These changes in rainfall patterns increase the likelihood of short-term crop failures and long-term production decline (BIPEN, 2012). Thus these same observations are made in Bembèrèkè and Malanville two municipalities located in the north of Benin. Therefore, expanding research on "Recent climate changes and socio-economic practices of maize production in the municipalities of Bembèrèkè and Malanville" is part of the promotion of results from UEMOA 2014 data. 


\section{STUDY AREA AND JUSTIFICATION OF THE RESEARCH}

The commune of Malanville, located in the extreme northeast of Benin in the department of Alibori, is located between $11^{\circ}$ 5 'and $12^{\circ} 00^{\prime}$ North latitude and $2^{\circ} 45^{\prime}$ and $3^{\circ} 40^{\prime}$ longitude East. It is bounded to the north by the Niger River, to the south by the Communes of Kandi and Ségbana, to the west by the Commune of Karimama and to the east by the Federal Republic of Nigeria (figure 1). It covers an area of 3,016 $\mathrm{km}^{2}$ subdivided into five (05) districts including Malanville, Garou, Madécali, Tomboutou and Guéné (Ahoyo, 2006). That of Bembèrèkè is between $10^{\circ} 00^{\prime}$ and $10^{\circ} 40^{\prime}$ north latitude and between $02^{\circ}$ 30 'and $03^{\circ} 00^{\prime}$ east longitude. Limited to the north by the commune of Gogounou, to the south by the commune of N'Dali, to the west by the commune of Sinendé and to the east by the commune of Nikki, this commune has an area of $3.348 \mathrm{~km}^{2}$ corresponding to $2,9 \%$ of the national territory. The agro-ecological characteristics of this area make it very vulnerable to the adverse effects of climate change (Gounou, 2016). According to the official report of MEHU (2001), North Benin is more affected by climate change than the South. Indeed, projections predict that precipitation will remain more or less stable in the southern part of the country while it will decrease by around 13 to $15 \%$ in the northern part by 2100 . Temperatures will generally increase. between $+2.6^{\circ} \mathrm{C}$ and $+3.2^{\circ} \mathrm{C}$ by 2100 throughout the country.

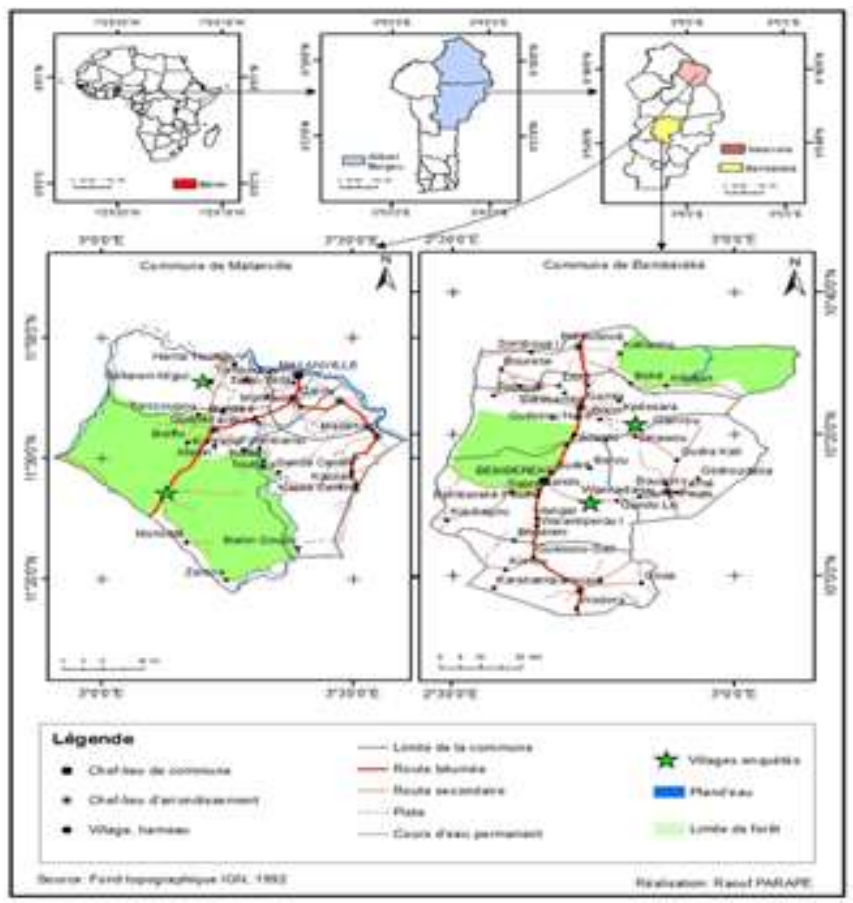

Figure 1: Map of the geographical location of the study area

\section{Research Rationale}

The traditional agrarian economy of this continent is insidiously bogged down, before our generally inattentive eyes through the manifestations of these climate changes. These manifestations are increasingly visible in developing countries. Benin, being one of these countries, suffers the impacts of climate change which slows down its development. This impact is particularly important in developing countries where agriculture is $100 \%$ rain-fed without any alternative to irrigation and constitutes the main source of employment and income for the majority of the population (Agossou, 2012; Delille, 2011 ; Enete, Onyekuru, 2011). The social construct and the economic constraints that underlie inequalities in access to productive resources are reinforced by climate change (Bridge, 2012, Bryant et al. 2000). The effects of climate change are manifested 
by global warming, low rainfall, droughts, but also floods at times (GWP / AO, 2010). According to the same source, to face this situation, adaptation measures are adopted by the grassroots populations with the support of technical services and technical and financial partners. Thus, these different measures range from endogenous traditional practices to proven technologies, including improved endogenous practices.

These practices also differ from one agro-climatic region to another, but they can be adapted for transfer to enhance adaptation (GWP / AO, 2010). This climate change will affect everyone in the medium to long term, that's for sure, but poor and marginalized communities will be the hardest hit (Neven, 2014). According to the same author these populations are already suffering today from the effects of droughts, water shortages, agricultural losses and changes in ocean regimes. Such changes only add to the pressures already exerted by other factors such as population growth or environmental degradation. It is feared that these pressures could lead to political and social instability (Neven, 2014).

The socio-economic development of the intertropical regions of the world and of Benin in particular, is closely linked to the capacity of the countries concerned to promote the agricultural sector which remains the most important sector there, due to the share of the national populations that it mobilizes, from the resources it provides to the national economy and its renewable nature (Aho and Kossou, 1997). In Benin, according to a UNDP report (2003), reported by (Yabi et al) agriculture in 2002 employed between 70 and $80 \%$ of working people and contributed in the same year to about $39 \%$ of the Gross Domestic Product. Thus, as Jama and Gonzalo (2008) point out, agricultural development is at the heart of poverty reduction and food security strategies in most developing countries.

For the intergovernmental panel on climate change, a drop in agricultural yields in West Africa could be between $5 \%$ and $2 \%$ in Benin. He goes on to note that this decline will not be uniform across agro-ecological zones. The economic impacts of Climate Change on agriculture show that yam and maize production will increase by 2050 (BIPEN, 2012). Thus, good practices for adapting to the adverse effects of climate change are defined as practices that make it possible to meet current needs and improve livelihoods, while preserving the environment in a sustainable manner in the current context of variability. and climate change (GWP / AO, 2010). According to the same source, concept of good practice is based on the application of available knowledge to the use of the natural resource base in a sustainable manner in order to obtain safe and healthy food and non-food products, while achieving sustainability. economic and social stability. To cope with the adverse effects of climate change, local populations have developed various adaptation strategies, either individually or collectively, based on endogenous knowledge. As for individual strategies, they include the management of crops and livestock, management of local soils and the diversification of sources of income (Pierre et al, 2012). According to the same source, producers have thus developed several adaptation measures such as abandoning certain crops or certain varieties such as peanuts and taro; adoption of new crops or varieties such as NERICA upland rice and early maize; the displacement of crops such as cassava and sweet potato according to landscape units; the modification of sown areas and the change of technical routes such as dry plowing for early sowing and finally the modification of rotations leading to a gradual change of the usual cropping calendar. Thus, they concluded by noting that diversification translates into the development of other activities parallel to agricultural production. Low agricultural yield depends both on the complex climate system of the African continent and on the interaction of this system with socio-political challenges such as governance and socio-economic challenges such as endemic poverty, limited access to markets for capital and global markets for product flows, ecosystem degradation, complex disasters and conflicts as well as urbanization that could undermine the ability of communities to adapt to climate change (Boko et al., 2007; FAO, 2008). 


\section{RESEARCH METHODLOGY}

\section{Data Collected and Collection Methods}

Two types of data were used: secondary data and primary data. Secondary data (climate change, perception and adaptation to climate change, etc.) are drawn from the literature throughout the project. Some additional secondary data was collected in different documentation centers in West Africa, notably in Benin. In addition, climatic data was collected from meteorological stations in the study area.

Primary data concern the socio-demographic characteristics of producers; the perception and adaptation strategies of producers; production systems, etc. The main method of collecting this primary data concerns surveys through structured and semi-structured interviews with the sampled producers. To this end, survey questionnaires were developed and administered. Table 1 shows the size of the sample chosen here.

Table I: Selected villages and sample size

\begin{tabular}{|l|l|l|l|l|l|}
\hline Country & Communes & Villages & $\begin{array}{l}\text { Number of } \\
\text { households }\end{array}$ & Sample size & $\begin{array}{l}\text { Sampling } \\
\text { rate (\%) }\end{array}$ \\
\hline \multirow{4}{*}{ Benin } & \multirow{3}{*}{ Malanville } & Sakawan-tegui & $\mathbf{1 7 6}$ & $\mathbf{3 5}$ & $\mathbf{2 0}$ \\
\cline { 3 - 6 } & Gembèrèkè & Goungoun & $\mathbf{7 2 3}$ & $\mathbf{3 5}$ & $\mathbf{5}$ \\
\cline { 3 - 6 } & & Ganrarou & $\mathbf{2 8 6}$ & $\mathbf{3 5}$ & $\mathbf{1 2}$ \\
\cline { 3 - 6 } & & $\mathbf{G a n}$ & $\mathbf{3 5}$ & $\mathbf{1 8}$ \\
\hline
\end{tabular}

Source: 2018 field surveys

Group discussions, participant observations, and data triangulation were also used as data collection tools. The data entry and management were carried out with SPSS 16.0 and Stata 10 statistical analysis software.

Such specifications have made it possible to understand the contribution of each adaptation strategy to the cost levels of controlling crop pest populations and to productivity levels. Later, from equation (2.3), the fourth step was a forecast of control costs and agricultural productivity from assumptions about inputs and climate change adaptation strategies. Finally, specific policy recommendations were formulated with the aim of improving agricultural productivity through adaptation to climate change and contributing to further strengthening food security.

Hypothesis 1: The populations perceive climate change according to their experiences and their level of education in the communes of Bembèrèkè and Malanville ".

The verification of this hypothesis consists in determining the degree of perception of climate change by corn producers. To do this, the distribution of producers according to the components of climatic events that have undergone changes was carried out. The frequencies were calculated in order to assess the degree of perception of the producers in relation to these different events.

Hypothesis 2: The farmer's experience, his area sown and his level of education influence a farmer's choice to opt for the use of a socio-economic practice.

To verify this hypothesis, the typology of socio-economic practices was carried out using the classification method which was based on Multiple Correspondence Analysis (MCA). It was used as classification criteria the socio-economic practices which are more used in the study cities namely: the different varieties, crop rotation, modification of the agricultural calendar, double sowing, increase of fertilizer use, increased pesticide use, and soil conservation practices. Also the 
distribution of farmers according to the typology of socio-economic practices is made, added Chi2 tests and ANOVA tests to highlight the dependencies that exist between the farmer's experiences, his sown area, his level of education. and socioeconomic practices of adaptation to climate change.

\section{Socio-economic and Demographic Characteristics of the Respondents}

\section{Descriptive Statistics of Qualitative Variables}

Several characteristics are unique to producers and even several of them explain the decisions they can make in choosing the cultivation practices to adopt. Thus, the study of the various socio-economic characteristics of producers in the two study municipalities, namely Bembèrèkè and Malanville, is of great importance. The essence of these characteristics which determine the decisions of the producer were thus presented.

The results of analysis of survey data show that men in the communes of Bembèrèkè and Malanvilles are more involved in agricultural activities than women (Figure 4). This fact is linked to their role as head of household and access to land. In addition, several empirical studies show that sex plays an important role in face decision making. Figure 1 illustrates this fact.

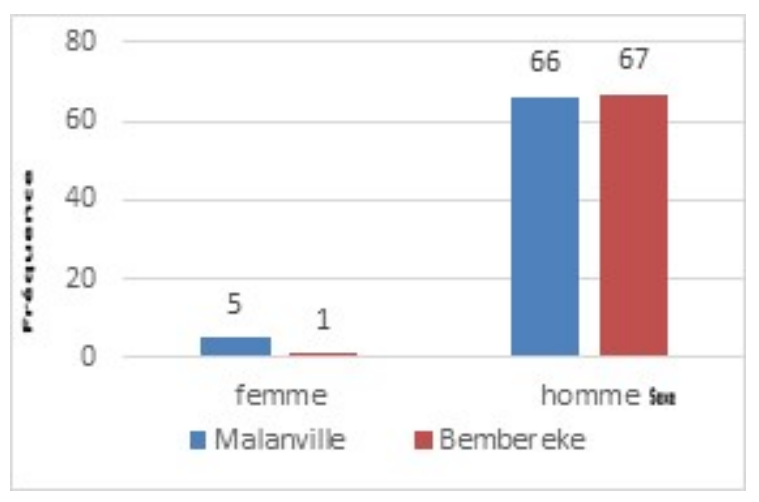

Figure 2: Breakdown of producers surveyed by sex

Source: Results of analysis of 2018 survey data

Figure 1 shows that overall, maize producers are $95.73 \%$ male. The low percentage of women $(4.27 \%)$ heads of households compared to men indicates that maize production activity in the study area is mainly male.

Level of education is a major factor in farming. Thus the analyzes show that $69.5 \%$ of the producers surveyed in the study area have no level of education. With regard to primary education, $15.6 \%$ of producers surveyed in the study area have primary education. It must be recognized that this level is not very efficient, the primary level being measured as a person having access to primary school without considering the class actually reached. Few of the producers surveyed claimed to have a secondary education level of cycles 1 and 2 . Some producers belong to a group.

Producers belonging to a group represent $61.4 \%$ of respondents. Within these groups they benefit from the advantages of group life. Among the producers, $58.9 \%$ surveyed have contact with researchers or extension agents because of their membership in a group.

In addition, it should be noted that $79.4 \%$ of respondents have taken part in an experiment or formal training in the field of agricultural production. 
Producers' access to credit is high (39.7\%) in the study area. Indeed, this percentage is low compared to the percentage of producers who do not have access to agricultural credit.

\section{Descriptive Statistics of Quantitative Variables}

Age, farming experience, number of farm workers and household size are very important variables used most often in econometric modeling studies. The statistical data in Table 3.1 indicate that the average age of producers surveyed in Bembèrèkè is 43.69 years while it is 39.79 in Malanville. Agriculture being the main activity of the research units, the agricultural experience of producers in this area is 20.17 years in Bembèrèkè with an average of 10.04 agricultural workers per household. In Malanville, it is 16.68 years with an average of 8.04 agricultural workers per household. As for the size of the household, it is 16.51 in Bembèrèkè and 11.30 in Malanville. Table II illustrates these quantitative variables.

Table II: Socio-economic characteristics of quantitative variables

\begin{tabular}{|l|l|l|l|l|}
\hline Variables & \multicolumn{2}{|l|}{ Malanville } & \multicolumn{2}{l|}{ Bembèrèkè } \\
\hline & Average & $\begin{array}{l}\text { Standard } \\
\text { deviation }\end{array}$ & Average & $\begin{array}{l}\text { Standard } \\
\text { deviation }\end{array}$ \\
\hline Age & 39.79 & 10.73 & 43.69 & 11.93 \\
\hline Experience & 16.51 & 14.33 & 20.17 & 12.59 \\
\hline $\begin{array}{l}\text { Agricultural } \\
\text { assets }\end{array}$ & 8.04 & 4.57 & 10.04 & 4.96 \\
\hline $\begin{array}{l}\text { Household } \\
\text { size }\end{array}$ & 11.30 & 8.07 & 16.51 & 8.19 \\
\hline
\end{tabular}

Source: Results of 2018 survey data analysis

\section{Local Perceptions of Climate Change}

The effects of climate change are mainly noticed through changes in manifestation: rain (96\%), heat (79\%) and wind (54\%). Table III shows the distribution of producers according to the components of climatic events that have undergone changes.

Table I : Répartition des producteurs selon les composantes des évènements climatiques subi des changements

\begin{tabular}{|l|l|l|}
\hline $\begin{array}{l}\text { Climatic events and } \\
\text { components }\end{array}$ & Number & $\begin{array}{l}\text { Percentages } \\
(\mathbf{\%})\end{array}$ \\
\hline Precipitation & $\mathbf{1 3 9}$ & $\mathbf{9 9 , 2 9}$ \\
\hline 1- Diminution & 131 & 93,57 \\
\hline 2- Precocity & 58 & 41,43 \\
\hline 3- Delay & 112 & 80 \\
\hline 4- Early stop & 113 & 80,71 \\
\hline $\begin{array}{l}\text { 5- Modification } \\
\text { Frequency / Distribution }\end{array}$ & 128 & 91,43 \\
\hline Temperature & $\mathbf{1 3 3}$ & $\mathbf{9 5}$ \\
\hline 1- Hotter & 112 & 80 \\
\hline 2- Colder than usual & 38 & 27.14 \\
\hline 3- Other & 13 & 9.29 \\
\hline Winds & $\mathbf{1 3 5}$ & $\mathbf{9 6 . 4 3}$ \\
\hline 1- Stronger wind & 115 & 82.14 \\
\hline 2- Medium strong wind & 24 & 17.14 \\
\hline
\end{tabular}

Source: Results of 2018 survey data analysis 


\section{Adaptations of Agricultural Techniques to Climate Change}

In this chapter, it was a question of making an inventory and typology of socio-economic practices.

Inventory of socio-economic practices used by producers in the face of climate change

The analysis of the table below indicates that the producers of the communes of Banikoara and Malanville mainly use: modification of the schedule $(91.43 \%)$, increase in the use of fertilizers $(66.43 \%)$, double sowing $(62.14 \%)$, increased use of pesticides (60\%), crop rotation (59.29\%), different varieties $(54.29 \%)$ and conservation of soil (53.57\%) as shown in Table IV.

\section{Table IV: Inventory of practices}

\begin{tabular}{|l|l|l|}
\hline \multicolumn{1}{|c|}{$\begin{array}{c}\text { Socio-economic } \\
\text { practices }\end{array}$} & Number & $\begin{array}{c}\text { Percentages } \\
\text { (\%) }\end{array}$ \\
\hline Different varieties & 76 & 54.29 \\
\hline Crop rotation & 83 & 59.29 \\
\hline Calendar modification & 128 & 91.43 \\
\hline Double sowing & 87 & 62.14 \\
\hline $\begin{array}{l}\text { Increase in fertilizer } \\
\text { use }\end{array}$ & 93 & 66.43 \\
\hline $\begin{array}{l}\text { Decrease in fertilizer } \\
\text { use }\end{array}$ & 25 & 17.86 \\
\hline $\begin{array}{l}\text { Increased use of } \\
\text { pesticides of }\end{array}$ & 84 & 60 \\
\hline $\begin{array}{l}\text { Decreased use } \\
\text { pesticides }\end{array}$ & 22 & 15.71 \\
\hline Soil conservation & 75 & 53.57 \\
\hline Agroforestry & 5 & 33.57 \\
\hline Irrigation field & 30 & 3.57 \\
\hline $\begin{array}{l}\text { Change of location } \\
\text { longe of activity }\end{array}$ & 9 & 6.43 \\
\hline Change & 29 & 20.71 \\
\hline Contract loans & 10 & 7.14 \\
\hline Migration & 29 & 20.71 \\
\hline Prayer or rituals & Source Results of 2018survey \\
\hline Sata ans
\end{tabular}

Source: Results of 2018 survey data analysis

These 7 socio-economic practices of adaptation to climate change have been the subject of this typology.

\section{Typology of socio-economic Practices to Deal with Climate Change}

The typology of socio-economic practices was carried out using the classification method based on Multiple Correspondence Analysis (MCA). We had used as classification criteria the socio-economic practices that are more used in the study cities, namely: the different varieties, crop rotation, modification of the agricultural calendar, double sowing, increased use. fertilizer, increased pesticide use, and soil conservation practices.

Thus, for the present Multiple Correspondence Analysis, use was made of 7 qualitative variables which have a total of 14 modalities which were all taken into account during the analysis.

\section{Choice of Factorial Axes}

For this analysis of multiple correspondences 7 eigenvalues which each generate a factorial axis. The Elbow criterion applied to these 7 eigenvalues allows us to retain the first two factorial axes. Because we observe a sudden drop at the level of the 
second axis. The first factorial axis explains $47.35 \%$ of the total inertia while the second axis contains only $17.86 \%$ of this total inertia. These first two factor axes then contain $65.21 \%$ of the information contained in all of the 7 projected variables as shown in Table V.

Table V: Distribution of the amount of inertia along the axes

\begin{tabular}{|l|l|l|l|}
\hline Number & $\begin{array}{l}\text { Own } \\
\text { value }\end{array}$ & Percentage & $\begin{array}{l}\text { Percentage } \\
\text { cumulated }\end{array}$ \\
\hline 1 & 0.4735 & 47.35 & 47.35 \\
\hline 2 & 0.1786 & 17.86 & 65.21 \\
\hline 3 & 0.0979 & 9.79 & 75.00 \\
\hline 4 & 0.0885 & 8.85 & 83.85 \\
\hline 5 & 0.0703 & 7.03 & 90.88 \\
\hline 6 & 0.0502 & 5.02 & 95.90 \\
\hline 7 & 0.0410 & 4.10 & 100.00 \\
\hline
\end{tabular}

Source: Analysis results of 2018 survey data

The typology of socio-economic practices to cope with climate change, which began with an analysis of multiple correspondences, ended with a hierarchical classification which made it possible to obtain 4 large homogeneous groups of farmers:

The first group of this classification contains $21.43 \%$ of the surveyed population. $63.83 \%$ and $53.57 \%$ respectively of the farmers who did not increase the use of fertilizers and of the farmers who did not increase the use of pesticides belong to this group. Thus, a farmer who belongs to this class has a $100 \%$ chance of not having increased the use of fertilizers and pesticides respectively. This group G1 is thus the group of farmers who do not make use of the increased use of fertilizers and pesticides.

The second group of this classification contains $26.43 \%$ of the surveyed population. $47.37 \%$ and $44.62 \%$ respectively of the farmers who do not make use of crop rotation and soil conservation practices belong to this second group. At the same time, a farmer belonging to this group has a $72.97 \%$ and $78.38 \%$ chance respectively of not having made use of crop rotation and soil conservation practices. This group G2 is therefore the group of farmers who do not make use of crop rotation and soil conservation practices.

The third group comprises $12.14 \%$ of the farmers surveyed. $91.67 \%$ and $19.64 \%$, respectively, of farmers who have not changed their cropping calendar and who have not increased pesticide use belong to this group. Not all farmers in this group make use of changing the cropping calendar and increasing use of pesticides, respectively. This group G3 is therefore the group of farmers who have not changed their cropping calendar and who have not increased the use of pesticides.

The fourth group is the largest group in this classification. It contains almost half of the farmers surveyed $(40 \%)$. $80 \%$ of farmers who use soil conservation practices belong to this group, $74.70 \%$ of farmers who do crop rotation, $70.11 \%$ of farmers who do double sowing, $71.43 \%$ of farmers who have increased pesticide use. When choosing an individual at random from this group, the chance of making use of conservation practices is $96.77 \% ; 100 \%$ chance of it doing crop rotation; $98.39 \%$ chance of double seeding and $96.77 \%$ chance of increasing pesticide use. This fourth group G4 is that of farmers who make use of soil conservation practices, crop rotation, double sowing, increased use of fertilizers, increased use of pesticides. and which do not make use of a different variety as shown in Table VI. 
Table VI: Distribution of farmers according to the typology of socio-economic practices

\begin{tabular}{|l|l|l|}
\hline $\begin{array}{c}\text { Farmer } \\
\text { groups }\end{array}$ & \multicolumn{1}{|c|}{ Dominant characteristics } & $\begin{array}{c}\text { Percentages } \\
(\%)\end{array}$ \\
\hline G1 & $\begin{array}{l}\text { Non-use of increased use of fertilizers } \\
\text { and pesticides }\end{array}$ & 21.43 \\
\hline G2 & $\begin{array}{l}\text { Non-use of crop rotation and soil } \\
\text { conservation practices }\end{array}$ & 26.43 \\
\hline G3 & $\begin{array}{l}\text { No modification of the cropping } \\
\text { calendar and no increase in the use of } \\
\text { pesticides }\end{array}$ & 12.14 \\
\hline G4 & $\begin{array}{l}\text { use of soil conservation practices, crop } \\
\text { rotation, double sowing, increased use of } \\
\text { fertilizers, increased use of pesticides } \\
\text { and no use of different varieties }\end{array}$ & 40.00 \\
\hline
\end{tabular}

Source: Results of 2018 survey data analysis

Table VII: Chi2 independence test between farmer groups and level of education

\begin{tabular}{|c|c|c|c|c|c|c|}
\hline \multirow{2}{*}{\multicolumn{2}{|c|}{ Farmer groups }} & \multicolumn{4}{|c|}{ Level of education } & \multirow{3}{*}{\begin{tabular}{|l|} 
Total \\
30 \\
\end{tabular}} \\
\hline & & \multirow{2}{*}{$\begin{array}{l}\text { None } \\
22\end{array}$} & \multirow{2}{*}{$\frac{\text { Primary }}{4}$} & \multirow{2}{*}{ 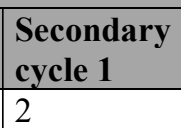 } & \multirow{2}{*}{$\begin{array}{l}\text { Secondary } \\
\text { cycle } 2\end{array}$} & \\
\hline & number & & & & & \\
\hline G1 & \begin{tabular}{|lr|}
\multicolumn{2}{|l}{ Percentage } \\
of & total \\
$(\%)$ &
\end{tabular} & 15.71 & 2.86 & 1.43 & 1.43 & 21.43 \\
\hline \multirow[b]{2}{*}{ G2 } & number & 29 & 4 & 4 & 0 & 37 \\
\hline & \begin{tabular}{|lr|}
\multicolumn{2}{|l|}{ Percentage } \\
of & total \\
$(\%)$ & \\
\end{tabular} & 20.71 & 2.86 & 2.86 & 0.00 & 26.43 \\
\hline \multirow[b]{2}{*}{ G3 } & number & 13 & 1 & 0 & 3 & 17 \\
\hline & \begin{tabular}{|lr|}
\multicolumn{2}{|l|}{ Percentage } \\
of & total \\
$(\%)$ &
\end{tabular} & 9.29 & 0.71 & 0.00 & 2.14 & 12.14 \\
\hline \multirow[b]{2}{*}{ G4 } & number & 35 & 13 & 7 & 1 & 56 \\
\hline & \begin{tabular}{|lr|}
\multicolumn{2}{|l|}{ Percentage } \\
of & total \\
$(\%)$ & \\
\end{tabular} & 25.00 & 9.29 & 5.00 & 0.71 & 40.00 \\
\hline \multirow[b]{2}{*}{ Total } & number & 99 & 22 & 13 & 6 & 140 \\
\hline & \begin{tabular}{|lr|}
\multicolumn{2}{|l}{ Percentage } \\
of & total \\
$(\%)$ &
\end{tabular} & 70.71 & 15.71 & 9.29 & 4.29 & 100 \\
\hline
\end{tabular}

Source: Results of 2018 survey data analysis

The analysis of this table reveals that $25 \%$ of the farmers surveyed have no level of education and belong to the G4 group; $20.71 \%$ of the farmers surveyed have no level of education and are in group G2. None of the farmers surveyed has a first cycle of second cycle education and does not belong to group G3. This is the case for the level of education of upper secondary school and membership of group G2. The Chi2 test performed at the 5\% threshold highlights a link between membership of a farmer group and level of education (Chi2 $=17.49$; dof $=9 \mathrm{p}$-value $=0.042)$. Under these conditions, we can conclude that the use of socio-economic practices to deal with climate change depends on the level of education of the farmer. In other words, the use of socio-economic practices varies according to the level of education. 
Table VIII: Chi2 independence test between group membership and cultivated maize area

\begin{tabular}{|c|c|c|c|c|c|}
\hline \multirow{2}{*}{\multicolumn{2}{|c|}{ Farmers group }} & \multicolumn{3}{|c|}{$\begin{array}{l}\text { Corn area cultivated } \\
\text { (in } \mathrm{Ha} \text { ) }\end{array}$} & \multirow{3}{*}{\begin{tabular}{|l|} 
Total \\
30 \\
\end{tabular}} \\
\hline & & \multirow{2}{*}{\begin{tabular}{|l|}
$\begin{array}{l}0 \\
10[\end{array}$ \\
24 \\
\end{tabular}} & \multirow{2}{*}{\begin{tabular}{|l|}
$10 ;$ \\
20[ \\
5 \\
\end{tabular}} & \multirow{2}{*}{\begin{tabular}{|l|}
{$[20 ;$} \\
$31]$ \\
1 \\
\end{tabular}} & \\
\hline & Number & & & & \\
\hline G1 & $\begin{array}{l}\text { Percentage of } \\
\text { total }(\%)\end{array}$ & 17.14 & 3.57 & 0.71 & 21.43 \\
\hline \multirow[b]{2}{*}{ G2 } & Number & 33 & 1 & 3 & 37 \\
\hline & $\begin{array}{l}\text { Percentage of } \\
\text { total }(\%)\end{array}$ & 23.57 & 0.71 & 2.14 & 26.43 \\
\hline \multirow[b]{2}{*}{ G3 } & Number & 16 & 1 & 0 & 17 \\
\hline & $\begin{array}{l}\text { Percentage of } \\
\text { total }(\%)\end{array}$ & 11.43 & 0.71 & 0.00 & 12.14 \\
\hline \multirow[b]{2}{*}{ G4 } & Number & 47 & 7 & 2 & 56 \\
\hline & $\begin{array}{l}\text { Percentage of } \\
\text { total }(\%)\end{array}$ & 33.57 & 5.00 & 1.43 & 40.00 \\
\hline \multirow[b]{2}{*}{ Total } & number & 120 & 14 & 0 & 140 \\
\hline & \begin{tabular}{|l}
$\begin{array}{l}\text { Percentage of } \\
\text { total }(\%)\end{array}$ \\
\end{tabular} & 85.71 & 10.00 & 4.29 & 100 \\
\hline
\end{tabular}

An analysis of this table indicates that $85.17 \%$ of the farmers surveyed sowed an area of maize less than or equal to 9 ha. Then, we can also make the remark that $33.57 \%$ of the respondents sowed an area of maize less than or equal to 9 ha and belong to group G4 and that almost all the farmers of group G3 sown an area of maize less than or equal at 9ha. The Chi2 test carried out at the $5 \%$ threshold shows that group membership and cultivated corn area are not related $(\mathrm{Chi}-2=7.46$; dof $=6 ; p$-value $=0.28$ ). Thus, the area of maize cultivated does not determine the choice of the producer to make use of such or such socio-economic practices to cope with climate change.

Table IX: ANOVA test to compare the average areas of corn sown according to the farmer's group

\begin{tabular}{|l|l|l|}
\hline Farmers group & $\begin{array}{c}\text { Average sown } \\
\text { areas }\end{array}$ & $\begin{array}{c}\text { Standard } \\
\text { deviations }\end{array}$ \\
\hline G1 & 6.13 & 4.47 \\
\hline G2 & 5.70 & 6.06 \\
\hline G3 & 4.96 & 3.01 \\
\hline G4 & 5.91 & 4.78 \\
\hline F $=\mathbf{0 . 2 2}$;dd1 $=\mathbf{3} ; \mathbf{d d l 2}=\mathbf{1 3 7} ;$ p-value $=\mathbf{0 . 8 8}$ \\
\hline
\end{tabular}

Source: Results of 2018 survey data analysis

The average area of maize cultivated by farmers in group G1 is 6.13 ha ( \pm 4.47$)$ compared to 5.70 ha $( \pm 6.06)$ among farmers in group G2. In group G3, the average area of maize sown is 4.96 ha ( \pm 3.01$)$ while in group G4 it is 5.91 ha ( \pm 4.78).

The present analysis of variance test carried out at this level has the null hypothesis: Equality between the average areas of maize according to the groups. After testing at the $5 \%$ threshold, we obtained a critical probability of 0.88 , which is greater than the conceded risk of error $(5 \%)$. We then accept the null hypothesis of this test $(\mathrm{F}(3 ; 137)=0.22 ; \mathrm{p}$-value $=$ 0.88). It then results from the test that the average cultivated maize area does not vary between the groups. Thus, socio- 
economic practices do not depend on the area of maize cultivated. The analysis of variance test result confirms the result of the Chi2 independence test between the maize area stored in interval classes and the farmer groups.

Table X: Chi2 independence test between farmer groups and farmers' experience

\begin{tabular}{|c|c|c|c|c|c|c|}
\hline \multirow{2}{*}{\multicolumn{2}{|c|}{ Farmers group }} & \multicolumn{4}{|c|}{ Farmers experience } & \multirow{3}{*}{\begin{tabular}{|l|} 
Total \\
30 \\
\end{tabular}} \\
\hline & & \multirow{2}{*}{\begin{tabular}{|l|}
{$\left[\begin{array}{l}\mathbf{0} \\
10[\end{array}\right.$} \\
9 \\
\end{tabular}} & \multirow{2}{*}{\begin{tabular}{l|}
{$\left[\begin{array}{ll}10 ; \\
20[\end{array}\right.$} \\
8 \\
\end{tabular}} & \multirow{2}{*}{ 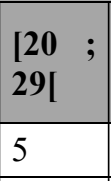 } & \multirow{2}{*}{\begin{tabular}{|l|}
$\begin{array}{l}{[30 \quad ;} \\
\text { et } \\
\text { plus }\end{array}$ \\
8 \\
\end{tabular}} & \\
\hline \multirow[b]{2}{*}{ G1 } & number & & & & & \\
\hline & $\begin{array}{l}\text { Percentage } \\
\text { of } \quad \text { total } \\
(\%)\end{array}$ & 6.43 & 5.71 & 3.57 & 5.71 & 21.43 \\
\hline \multirow[b]{2}{*}{ G2 } & number & 9 & 17 & 7 & 4 & 37 \\
\hline & 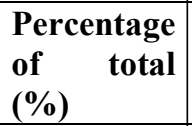 & 6.43 & 12.14 & 5.00 & 2.86 & 26.43 \\
\hline \multirow[b]{2}{*}{ G3 } & number & 6 & 7 & 0 & 4 & 17 \\
\hline & $\begin{array}{l}\text { Percentage } \\
\text { of } \quad \text { total } \\
(\%)\end{array}$ & 4.29 & 5.00 & 0.00 & 2.86 & 12.14 \\
\hline \multirow[b]{2}{*}{ G4 } & number & 11 & 13 & 16 & 16 & 56 \\
\hline & $\begin{array}{ll}\text { Percentage } \\
\text { du } & \text { total } \\
(\%) & \\
\end{array}$ & 7.86 & 9.29 & 11.43 & 11.43 & 40.00 \\
\hline \multirow[b]{2}{*}{ Total } & number & 35 & 45 & 28 & 32 & 140 \\
\hline & 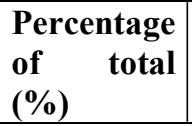 & 25.00 & 32.14 & 20.00 & 22.86 & 100 \\
\hline \multicolumn{7}{|c|}{ Valeur du Chi2 $=14.95 ;$ ddl $=9 ;$-value $=0.092$} \\
\hline
\end{tabular}

Source: Results of 2018 survey data analysis

The examination of this table shows that $32.14 \%$ of the farmers surveyed have experience of between 10 and 19 years and $22.86 \%$ of them have experience greater than or equal to 20 years and belong to group G4. The chi2 test carried out at this level at the $5 \%$ threshold reveals that belonging to a farmer group is not linked to the farmer's experience (Chi-2 $=14.95$; dof $=9 ; p$-value $=0.092$ ). The experience of farmers therefore does not determine the socio-economic practices for dealing with climate change.

Table XI: ANOVA test to compare the average experience according to the farmer's group

\begin{tabular}{|l|l|l|}
\hline \multicolumn{1}{|c|}{ Farmers group } & \multicolumn{1}{|c|}{$\begin{array}{c}\text { Average } \\
\text { experiences }\end{array}$} & $\begin{array}{c}\text { Standard } \\
\text { deviations }\end{array}$ \\
\hline G1 & 18.79 & 13.97 \\
\hline G2 & 15.57 & $\mathbf{8 . 9 5}$ \\
\hline G3 & 20.06 & 23.17 \\
\hline G4 & 19.00 & 11.95 \\
\hline F $=0.61 ;$ ddl1 $=$ 3; dd12 $=137 ;$ p-value $=\mathbf{0 . 6 1}$ \\
\hline
\end{tabular}

Source: Results of 2018 survey data analysis

Within group G1, farmers have an average experience of 18.79 years $( \pm 13.97)$ while in group G4 the average experience is 19 years $( \pm 11.95)$. For the G2 group, this average experience is 15.57 years $( \pm 8.95)$ compared to 20.06 years 
$( \pm 23.17)$ in the G3 group.

The critical probability of this ANOVA test is 0.61 . This critical probability being greater than the risk of error conceded (5\%), the null hypothesis of the ANOVA test which consists in that the average experiences are equal between them; will be accepted. In other words, the results of this ANOVA test, highlight an absence of dependence between belonging to a group and the experience of the farmer $(\mathrm{F}(3 ; 137)=0.61 ; \mathrm{p}$-value $=0.61)$. Socio-economic practices for dealing with climate change are not determined by the experience of farmers. The result of this ANOVA test confirms the result of the $\mathrm{Chi} 2$ independence test.

\section{CONCLUSIONS}

It emerges from the study that in general, corn producers are aware of the phenomenon of climate change. However, the level of perception of changes related to precipitation and temperature is higher than that of the perception of events related to wind speed. These producer perceptions are consistent with the rainfall and thermal variability recorded in recent years.

So after analysis, we can conclude that the use of socio-economic practices to deal with climate change depends on the level of education of the farmer. In other words, the use of socio-economic practices varies according to the level of education.

Also, the area of corn cultivated does not determine the producer's choice to make use of such or such socioeconomic practices to cope with climate change. Thus, the result of the analysis of variance test confirms the result of the Chi2 independence test between the maize area stored in interval classes and the farmer groups. Finally, it is noted that socioeconomic practices for dealing with climate change are not determined by the experience of farmers. The result of this ANOVA test confirms the result of the Chi2 independence test.

\section{REFERENCES}

1. Aho N. et Kossou D. (1997) : Précis d'agriculture tropicale, Base et Eléments d'Application,edition Flamboyant. 464 p.

2. BIPEN (2012): Implications économiques des changements climatiques dans le secteur agricole, 115p

3. Boko M.; Niang I.; Nyong A.; Vogel C.; Githeko A.; Medany M.; Osman E.; Tabo B. R. YANDA P. (2007): Climate change: Impacts, Adaptation and Vulnerability. pp. 433-67. In: Parry, M.L., Canziani, O.F., Palutikof, J.P., van der Linden, P.J. and Hanson, C.E. (Eds.). Climate change 2007: Impacts, adaptation and vulnerability. Contribution of Working Group II to the Fourth Assessment Report of the Intergovernmental Panel on Climate Change (Cambridge: Cambridge University Press.

4. CANADA, 2014 : vivre avec les changements climatiques au canada : perspectives des secteurs relatives aux impacts et à l'adaptation, Gouvernement du canada, 292p

5. GWP / AO, 2010 : Sécurité en eau et développement résilient, Global Water Partnership Global Secretaria Drottninggatan 33 SE-111 51 Stockholm Suède, 39p

6. Jama B. et \& Gonzalo P. 2008. Agriculture in Africa : Strategies to Improve and Sustain Smallholder Production Systems. Ann. N.Y. Acad. Sci. New York $1136: 218-2$

7. MEHU, (2011). Deuxième Communication Nationale de la République du Bénin sur les Changements Climatiques. Bénin, MEHU, Cotonou. $168 p$ 
8. Pierre V. Vissoh, Rigobert C. Tossou, Houinsou Dedehouanou, Hervé Guibert, Olivier C. Codjia, Simplice D. Vodouhe et Euloge K. Agbossou, 2012 : Perceptions et stratégies d'adaptation aux changements climatiques : le cas des communes d'Adjohoun et de Dangbo au Sud-Est Bénin, Article publié au revue cahier d'outre mer, p. 479-492

9. Renard J. F., Cheikh L. \& Knips V. 2004. L'élevage et l'intégration régionale en Afrique de l'Ouest, Ministère des Affaires étrangères - FAO-CIRAD, 37 p.

10. UE,2015 : Les défis de l'Afrique face au changement climatique Rapport de groupe interparlementaire d'amitié $n^{\circ} 130-5$ novembre 2015

11. Yabi A. J. ; Paraïso A. A. (2014): Managing the agricultural calendar as coping mechanism to climate variability: A case study of maize farming in northern Benin, West Africa.

12. Yabi, A. J. (2010) : Analyse des déterminants de la rentabilité économique des activités menées par les femmes rurales dans la commune de Gogounou au Nord-Bénin. Annales des Sciences Agronomiques 14 (2) pp 221-239. 

